\title{
Buffy Coat and Serum Concentration of Potassium Related to the Acid-base Status in Dogs Following Induced Hypokalemia
}

\author{
J. AGUILAR-BOBADILLA ${ }^{1}$, J. BOUDA² ${ }^{2}$ L. NÚÑEZ-OCHOA ${ }^{2}$, C. VÁSQUEZ-PELÁEZ ${ }^{3}$ \\ ${ }^{1}$ Department of Small Animal Medicine, \\ ${ }^{2}$ Department of Pathology, Section of Clinical Pathology \\ ${ }^{3}$ Department of Genetics and Statistics, Faculty of Veterinary Medicine, \\ National Autonomous University of Mexico, 04510, Mexico City, Mexico
}

Received October 10, 2004

Accepted June 6, 2005

\begin{abstract}
Aguilar-Bobadilla J., J. Bouda, L. Núñez-Ochoa, C. Vásquez-Peláez: Buffy Coat and Serum Concentration of Potassium Related to the Acid-base Status in Dogs Following Induced Hypokalemia. Acta Vet Brno, 2005, 74: 225-232.
\end{abstract}

Electrolyte and acid-base disturbances are frequent in sick dogs. The objective of this study was to determine the concentration of $\mathrm{K}^{+}$in blood serum and buffy coat $\mathrm{K}^{+}\left(\mathrm{BC} \mathrm{K}^{+}\right)$and its relation to other serum electrolytes and acid-base values in blood of healthy dogs and those with hypokalemia induced by furosemide. The study was performed on 42 dogs of both sexes, aged 3 to 8 years, divided into two groups. Group 1 (control, $\mathrm{n}=21$ ) included healthy dogs, Group 2 (experimental, $\mathrm{n}=21$ ) consisted of healthy dogs in which hypokalemia had been induced using furosemide at a dose of $12 \mathrm{mg} / \mathrm{kg}$ PO BID during 21 days. Physical examination, haemogram (16 analytes), biochemical profile (22 analytes) and urinalysis ( 15 analytes) were performed to evaluate the health status of all dogs. In this study, the most important serum analytes were $\mathrm{Na}^{+}, \mathrm{K}^{+}$and $\mathrm{Cl}^{-} ; \mathrm{BC} \mathrm{K}^{+}$ and blood $\mathrm{pH}, \mathrm{HCO}_{3}^{-}$, base excess (BE), as well as $\mathrm{pCO}_{2}$. A method for obtaining $\mathrm{BC}$ and determining intracellular $\mathrm{K}^{+}$was developed. Between groups 1 and 2, serum $\mathrm{K}^{+}$had a significant correlation with $\mathrm{pH}, \mathrm{HCO}_{3}{ }^{-}$and $\mathrm{BE}(r>0.6, p<0.01)$; in addition, in Group 2 there was a significant correlation with $\mathrm{Na}^{+}$and $\mathrm{Cl}^{-}(r>0.7, p<0.01)$, due to the furosemide effect. The $\mathrm{BC} \mathrm{K}^{+}$presented low correlation with serum $\mathrm{K}^{+}$, as well as with other variables, and thus could not be considered a good indicator of intracellular $\mathrm{K}^{+}$. The correlation coefficients in groups 1 and 2 were significant between strong ion difference (SID), $\mathrm{K}^{+}, \mathrm{Cl}^{-}, \mathrm{HCO}_{3}{ }^{-}$and $\mathrm{BE}(r>0.7, p<0.01)$, suggesting SID as a good indicator of $\mathrm{K}^{+}$translocation in metabolic alkalosis. The anion gap (AG) did not present significant correlation with $\mathrm{BC} \mathrm{K}+$, with serum $\mathrm{Na}^{+}, \mathrm{K}^{+}$and $\mathrm{Cl}^{-}$, or with $\mathrm{pH}, \mathrm{HCO}_{3}^{-}, \mathrm{BE}$ and $\mathrm{pCO}_{2}$. For the evaluation of electrolyte alterations and metabolic acid-base disorders it is necessary to include in laboratory profiles the determination of $\mathrm{K}^{+}, \mathrm{Na}^{+}, \mathrm{Cl}^{-}, \mathrm{HCO}_{3}{ }^{-}$in blood serum, as well as to calculate AG, SID, and relate them to the physical examination of the animal.

Dog, furosemide, buffy coat potassium, serum electrolyte, acid-base status

Acid-base and electrolyte disturbances are frequently present in sick dogs. Approximately $95 \%$ of the total potassium $\left(\mathrm{K}^{+}\right)$is intracellular, of which 60 to $75 \%$ is contained in the muscles, thus causing it to be the main ion at this level (MacIntire 1997; Phillips and Polzin 1998). $\mathrm{K}^{+}$maintains intracellular volume and a normal membrane potential (Bilbrey et al. 1973; Field et al. 1987). In healthy animals, daily intake of $\mathrm{K}^{+}$equals the losses. In extracellular fluid (ECF) the average sodium $\left(\mathrm{Na}^{+}\right)$concentration is 150 $\mathrm{mmol} / \mathrm{L}$ and that of $\mathrm{K}^{+}$is $4 \mathrm{mmol} / \mathrm{L}$. In dogs, the $\mathrm{Na}^{+}: \mathrm{K}^{+}$proportion in intracellular fluid (ICF) is inverted. Experimental studies in healthy dogs have muscle tissue $\mathrm{Na}^{+}$and $\mathrm{K}^{+}$levels ranging from 8.4 to $13.7 \mathrm{mmol} / \mathrm{L}$ and 139 to $142 \mathrm{mmol} / \mathrm{L}$, respectively (Phillips and Polzin 1998).

One study, in dogs, determined total $\mathrm{K}^{+}$concentration to be $47.1 \mathrm{mmol} / \mathrm{kg}$ of body weight, ranging from 39.8 to $61.1 \mathrm{mmol} / \mathrm{kg}$ (Di Bartola and De Morais 2000). The normal proportion of extracellular and intracellular potassium is maintained by the sodium-

Address for correspondence:

Prof. MVDr. J. Bouda, DrSc.

Departamento de Patología

Facultad de Medicina Veterinaria

Universidad Nacional Autónoma de México, Ciudad Universitaria

Av. Universidad 3000, Col. Copilco, México, D.F. 04510

Phone and Fax: (01 55) 56225878

E-mail: bouda@servidor.unam.mx

http://www.vfu.cz/acta-vet/actavet.htm 
potassium pump found in cell membranes. This pumps $\mathrm{Na}^{+}$ions out and $\mathrm{K}^{+}$ions into the cell at a 3:2 ratio (Di Bartola and De Morais 2000; Hendrix and Raffe 1994). The ability of specialized cells to develop a membrane potential is crucial for normal cardiac conduction, muscular contraction and the transmission of nervous impulses (Di Bartola and De Morais 2000; Kornegay 1995). $\mathrm{K}^{+}$homeostasis in the organism is maintained through dietary intake and excretion in urine (Di Bartola and De Morais 2000). Changes in $\mathrm{pH}$ can produce $\mathrm{K}^{+}$translocation between ICF and ECF. In general, acidosis is associated with the movement of $\mathrm{K}^{+}$from ICF to ECF, while during alkalosis $\mathrm{K}^{+}$ions move in the opposite direction (Ilkiw et al. 1989; Schaer 1993; Di Bartola and De Morais 1993; Di Bartola et al. 1994).

Hypokalemia is one of the most frequently encountered electrolyte disturbances in critical patients. It presents when there is a lack of nutrients, such as in anorexia, or when there are excessive losses during vomiting (Bellenger et al. 1990). Polyuria also causes hypokalemia, be it from chronic renal failure or any type of polyuric diuresis, such as: release of a urinary tract obstruction, nephrogenic diabetes insipidus (Phillips and Polzin 1998; Di Bartola and De Morais 2000); prostatic abscesses or pyometra, both of which cause E. coli toxin deposition in renal tubules with subsequent interference on $\mathrm{Na}^{+}$and $\mathrm{Cl}^{-}$ absorption; medullary washout; and the use of loop diuretics (Di Bartola and De Morais 2000). Finally, hypokalemia is also seen with translocation of potassium into ICF during respiratory or metabolic alkalosis (MacIntire 1997).

In animals with diabetic ketoacidosis, the level of $\mathrm{K}^{+}$in serum can drop after insulin treatment, since this favors the entrance of potassium into the ICF. Correcting the acidotic state also reverts the translocation; thus the importance of monitoring serum $\mathrm{K}^{+}$in diabetic patients (Schaer 1993a). Hypokalemia, induced by $\mathrm{K}^{+}$translocation to ICF, is observed in dogs with hyperventilatory respiratory alkalosis (Muir et al. 1990). Both in hypo- and hyperkalemia, the proportion of intracellular (IC) and extracellular (EC) $\mathrm{K}^{+}$is altered, and the membrane potentials in excitable heart tissue, nerves and muscles are affected, producing altered conduction rates (MacIntire 1997). The reference range for kalemia in dogs is from 3.92 to $5.54 \mathrm{mmol} / \mathrm{L}$, thus defining hypokalemia as values lower than those referred and hyperkalemia as values higher than reference values (Kirk 1980; Núñez 2001).

The only practical measurement of the change of body $\mathrm{K}^{+}$is the concentration of $\mathrm{K}^{+}$in serum; representing only $5 \%$ of the total given that $95 \%$ is found in the IC level (Phillips and Polzin 1998). With this in mind, the aim of the present study was to determine the relationship between $\mathrm{K}^{+}$in the buffy coat (BC) with that observed in serum, as well as of both of these with the acid-base evaluation in healthy dogs and those in which hypokalemia had been induced.

\section{Materials and Methods}

Forty-two clinically healthy dogs of both sexes, aged three to eight years, were divided into two groups. Group 1 (control) consisted of 21 healthy dogs, ten German shepherds (seven males and three females) and 11 mixedbreed dogs (three females and eight males). Physical examination, haemogram (16 analytes), biochemical profile (22 analytes) and urinalysis (15 analytes) were performed to evaluate the health status of all dogs. None of them showed any alterations in the haematological indices, serum biochemistry or urinalysis (Le es et al. 1994; Núñez 2001). Group 2 (experimental) was made up of 21 mixed-breed dogs (nine females and 12 males) in which hypokalemia $(<3.8 \mathrm{mmol} / \mathrm{L})$ had been induced using furosemide at a dosage rate of $12 \mathrm{mg} / \mathrm{kg}$ PO BID during 21 days (Bonagura et al. 2000; Senior 1995).

Blood samples were obtained from either the jugular or cephalic vein, after an eight-hour fast. The urine samples were collected via catheterization or cystocentesis. Procedures were developed to obtain the buffy coat (BC) and determine intracellular $\mathrm{K}^{+}$. Venous blood samples were collected in vacuum tubes (Vacutainer ${ }^{\circledR}$ ) containing sodium heparin. Blood components were separated using a relative centrifugal force (RCF) of $1200 \mathrm{~g}$ during 10 min, thus obtaining red blood cells, buffy coat and plasma. The plasma was decanted and approximately one $\mathrm{mL}$ of BC containing red blood cells was removed to fill a Wintrobe tube. A second centrifugation at $1200 \mathrm{~g}$ for $10 \mathrm{~min}$ was carried out, this separated the components leaving the red blood cells on the bottom and the buffy coat on the 
top. A Hamilton syringe was used to obtain $20 \mu \mathrm{L}$ of $\mathrm{BC}$, to which $380 \mu \mathrm{L}$ of demineralized water was added in microtubes, thus obtaining a $1 / 20$ dilution.

Intracellular $\mathrm{K}^{+}$was obtained by successively freezing at $-10{ }^{\circ} \mathrm{C}$ and heating to $60{ }^{\circ} \mathrm{C}$ three times, thus causing cell destruction. The cellular destruction in the $\mathrm{BC}$ was confirmed through cytological examination of each sample in which cell debris was the only finding, thus indicating complete cell destruction. The concentration of $\mathrm{K}^{+}$was determined by means of Electrolyte analyzer, Model 644 (Ciba Corning). To confirm procedure reliability, a tentime estimate of the same sample was carried out.

Acid-base status was determined in blood taken in a heparinized syringe, removing air bubbles and the needle was inserted into a rubber stopper to avoid contact with atmospheric air and then the syringe was immersed in a mixture of ice and water. These samples were analysed by $\mathrm{pH} / \mathrm{blood}$ gas analyser, Model 238 (Ciba Corning) within $1 \mathrm{~h}$ after blood sampling (obtaining $\mathrm{pH}$, partial pressure of $\mathrm{CO}_{2}\left(\mathrm{pCO}_{2}\right)$, bicarbonate $\left(\mathrm{HCO}_{3}{ }^{-}\right)$and base excess $(\mathrm{BE})$.

The biochemical profile was carried out on blood obtained in plain vacuum tubes $\left(\right.$ Vacutainer $\left.^{\circledR}\right)$. After the clot had fully formed, the samples were centrifuged at $1200 \mathrm{~g}$ during $10 \mathrm{~min}$ and serum was transferred into microtubes. In the following 4 hours a Biochemical analyser (Cobas Mira, Roche Switzerland) was used to determine the following serum analytes: glucose, urea, creatinine, alanine aminotransferase (ALT), aspartate aminotransferase $(\mathrm{AST})$, creatin kinase $(\mathrm{CK})$, total proteins, albumin, globulins, calcium, phosphate and total $\mathrm{CO}_{2}\left(\mathrm{TCO}_{2}\right)$, while potassium $\left(\mathrm{K}^{+}\right)$, sodium $\left(\mathrm{Na}^{+}\right)$and chloride $\left(\mathrm{Cl}^{-}\right)$were determined by the electrolyte analyzer model $644 \mathrm{Ciba}$ Corning). Anion gap (AG) was calculated using the following formula: $\mathrm{AG}=\left(\mathrm{Na}^{+}+\mathrm{K}^{+}\right)-\left(\mathrm{Cl}^{-}+\mathrm{HCO}_{3}^{-}\right)$. The strong ion difference (SID) was calculated by clinical approach and corresponded to the difference between $\mathrm{Na}^{+}$ and $\mathrm{Cl}^{-}$(Russell et al. 1996).

Venous blood samples for haemogram (packed cell volume, haemoglobin, red blood cell count, mean corpuscular volume, mean corpuscular haemoglobin concentration, reticulocytes, white blood cell count, platelet count, plasma proteins, leukocyte differential count - neutrophils, band neutrophils, lymphocytes, monocytes, eosinophils, basophils, red blood cell and leukocyte abnormal morphology) were obtained in vacuum tubes (Vacutainer ${ }^{\circledR}$ ) containing EDTA. Cells counts were carried out less than three hours after sampling, using automated equipment Celldyn Analyser 3500R, Abbott Laboratories. Differential leukocyte count was determined employing the manual method upon a Wright stained blood smear (Knoll 2000).

Urinalysis included physical exam (appearance, density), chemical exam ( $\mathrm{pH}$, protein, glucose, ketones, bilirubin, urobilinogen, blood) using urine strips, Multistix ${ }^{\circledR}$ Ames and microscopic examination of the sediment (leucocytes, erythrocytes, epithelial cells, casts, crystals, bacteria. Urine sediment examination was performed by standardized procedures according to Brobst (1989) and Meyer et al. (1992).

The statistical analysis determined the variation coefficient of $\mathrm{K}^{+}$in $\mathrm{BC}$ in order to calculate its repeatability. The difference between groups was carried out using Student's $t$-test. The relationship between the concentration of $\mathrm{K}^{+}$in serum and BC with that of other electrolytes and the values of acid-base status in blood, was determined using the Pearson correlation coefficient. Pearson's coefficient correlation was also calculated for SID, AG and $\mathrm{Na}+\mathrm{K}+$ relationship with serum electrolytes and acid-base values. This was done in order to understand the relationship of the traditional and non-traditional methods with the electrolyte concentration. Statistical analyses were carried out using the SAS statistical package (1990).

\section{Results}

Means for serum $\mathrm{Na}^{+}, \mathrm{K}^{+}$and $\mathrm{Cl}^{-}, \mathrm{BC} \mathrm{K}^{+}$as well as values for acid-base status in blood $\left(\mathrm{pH}, \mathrm{HCO}_{3}^{-}, \mathrm{BE}\right.$ and $\left.\mathrm{pCO}_{2}\right)$ for healthy animals are shown in Table 1.

Buffy coat values of $\mathrm{K}^{+}$in the control group were $32.84 \pm 2.34 \mathrm{mmol} / \mathrm{L}$, while for $\mathrm{K}^{+}$in serum, they were $4.77 \pm 0.59$. In Group 2 , furosemide administration caused a decrease of $\mathrm{K}^{+}$in $\mathrm{BC}$, as well as hypokalemia, hyponatremia, hypochloremia and an increase in $\mathrm{pH}$, $\mathrm{HCO}_{3}^{-}$and $\mathrm{BE}$, due to metabolic alkalosis and an increase in $\mathrm{pCO}_{2}$ (Table 1).

Differences for serum $\mathrm{Na}^{+}, \mathrm{K}^{+}$, and $\mathrm{Cl}^{-}, \mathrm{BC} \mathrm{K}^{+}$and for acid-base values $(p<0.05)$ were observed. The correlation coefficient between groups, for serum $\mathrm{K}+$ with $\mathrm{BC} \mathrm{K}+$, was nonsignificant $(\mathrm{r}<0.6)$. There was a negative correlation greater than 0.6 with $\mathrm{pH}, \mathrm{HCO}_{3}^{-}$and $\mathrm{BE}$; and a positive correlation greater than 0.7 with $\mathrm{Na}^{+}$and greater than 0.8 with $\mathrm{Cl}^{-}$. The correlation coefficient between $\mathrm{K}^{+}$in $\mathrm{BC}$ and serum $\mathrm{K}^{+}$with the rest of the electrolytes and acid-base values was lower than 0.6 , negative with $\mathrm{pH}, \mathrm{HCO}_{3}{ }^{-}$and $\mathrm{BE}$ and positive with the rest of the electrolytes (Table 2).

Pearson's correlation coefficient for SID, AG and $\mathrm{Na}^{+}: \mathrm{K}^{+}$with $\mathrm{Na}^{+}$and $\mathrm{Cl}^{-}$in serum, as well as with $\mathrm{pH}, \mathrm{HCO}_{3}^{-}, \mathrm{BE}$ and $\mathrm{pCO}_{2}$ produced the following results: SID has a positive and significant correlation with $\mathrm{pH}$ which is greater than 0.6; likewise for $\mathrm{HCO}_{3}^{-}$and $\mathrm{BE}$, though in this case greater than 0.7; SID correlations with serum $\mathrm{K}^{+}$and $\mathrm{Cl}^{-}$are significant 
Table 1. Means for serum $\mathrm{Na}^{+}, \mathrm{K}^{+}$and $\mathrm{Cl}^{-}$, buffy coat $\mathrm{K}^{+}$as well as values for acid-base status in blood (Group 1, control, $\mathrm{n}=21$ ) and in dogs with hypokalemia caused by furosemide administration (Group 2, experimental, $\mathrm{n}=21$ )

\begin{tabular}{|c|c|c|c|c|c|c|c|c|c|c|c|}
\hline \multirow[t]{2}{*}{ Analyte } & $\mathbf{K}^{+}$ & $\mathrm{BC} \mathrm{K}^{+}$; & $\mathrm{HCO}_{3}$ & $\underset{n o l / L}{\mathrm{Cl}^{-}}$ & $\mathrm{Na}^{+}$ & BE & $\mathrm{pH}$ & $\begin{array}{r}\mathrm{pCO}_{2} \\
\mathrm{~mm} / \mathrm{Hg}\end{array}$ & SID & $\underset{\mathrm{mmo} / \mathrm{L}}{\mathrm{AG}}$ & $\mathrm{Na}^{+}: \mathrm{K}^{+}$ \\
\hline & \multicolumn{11}{|c|}{ GROUP 1} \\
\hline Mean & $4.73 a$ & $33.19 \mathrm{a}$ & $18.0 \mathrm{a}$ & $113.7 \mathrm{a}$ & $147.5 \mathrm{a}$ & $-7.04 \mathrm{a}$ & $7.38 \mathrm{a}$ & $30.7 \mathrm{a}$ & $33.8 \mathrm{a}$ & $20.4 \mathrm{a}$ & $31.5 \mathrm{a}$ \\
\hline SD & 0.54 & 2.44 & 1.4 & 3.3 & 3.6 & .72 & 0.031 & 3.6 & 2.8 & 3.0 & 3.3 \\
\hline Lower & 3.84 & 30 & 16 & 108 & 140 & -11.9 & 7.31 & 25 & 30 & 16.1 & 25.3 \\
\hline Upper & 5.99 & 37.4 & 20.7 & 119 & 153 & -4.0 & 7.44 & 39 & 40 & 26.1 & 37.6 \\
\hline \multicolumn{12}{|c|}{ GROUP 2} \\
\hline Mean & $3.45 \mathrm{~b}$ & $27.69 \mathrm{~b}$ & $24.7 \mathrm{~b}$ & $94.4 \mathrm{~b}$ & $137.6 \mathrm{~b}$ & $-1.68 b$ & $7.43 \mathrm{~b}$ & $34.4 \mathrm{~b}$ & $43.1 \mathrm{~b}$ & $21.9 \mathrm{~b}$ & $39.9 \mathrm{~b}$ \\
\hline SD & 0.22 & 6.42 & 2.8 & 4.3 & 5.4 & 2.7 & 0.041 & 4.5 & 3.3 & 3.7 & 3.0 \\
\hline Lower & 2.84 & 13.2 & 19.4 & 88.0 & 131.0 & -6.8 & 7.34 & 29.0 & 39 & 14.5 & 36.1 \\
\hline Upper & 3.77 & 37.0 & 29.5 & 106.0 & 156.0 & 4.6 & 7.5 & 44.0 & 50 & 27.7 & 47.1 \\
\hline
\end{tabular}

$\mathrm{K}+$; serum potassium, $\mathrm{BC} \mathrm{K}^{+}$; buffy coat potassium, $\mathrm{Na}^{+}$; serum sodium, $\mathrm{Cl}^{-}$; serum chloride, $\mathrm{HCO}_{3}^{-}$, bicarbonate, $\mathrm{BE}$; base excess, $\mathrm{pCO}_{2}$; partial pressure of $\mathrm{CO}_{2}$ in blood, $\mathrm{SID}$; strong ion difference, $\mathrm{AG}$; anion gap, $\mathrm{Na}^{+}: \mathrm{K}^{+}$; ratio sodium-potassium; a, b values $(p<0.5)$

Table 2. Pearson's coefficient correlation of serum electrolytes, buffy coat potassium and blood acid-base values in healthy animals (Group 1, control, $\mathrm{n}=21$ ) and in dogs with hypokalemia caused by furosemide administration (Group 2, experimental, $\mathrm{n}=21$ )

\begin{tabular}{|c|c|c|c|c|c|c|c|c|}
\hline Analyte & $\mathbf{K}^{+}$ & $\mathbf{B C ~ K}^{+}$ & pH & $\mathrm{HCO}_{3}^{-}$ & $\mathrm{Cl}^{-}$ & $\mathbf{N a}^{+}$ & BE & $\mathrm{pCO}_{2}$ \\
\hline \multirow[t]{2}{*}{$\mathbf{K}^{+}$} & 1.00000 & 0.40569 & -0.63820 & -0.67244 & 0.84461 & 0.70701 & -0.60396 & -0.32784 \\
\hline & 0 & $<0.0001$ & $<0.0001$ & $<0.0001$ & $<0.0001$ & $<0.0001$ & $<0.0001$ & 0.0340 \\
\hline \multirow[t]{2}{*}{$\mathbf{B C ~ K}^{+}$} & & 1.00000 & -0.32218 & -0.47798 & 0.56655 & 0.58889 & -0.40064 & -0.22933 \\
\hline & & & 0.0375 & 0.0014 & $<0.0001$ & $<0.0001$ & 0.0086 & 0.1440 \\
\hline \multirow[t]{2}{*}{ pH } & & & 1.00000 & 0.65936 & -0.61042 & -0.44589 & 0.70806 & -0.12729 \\
\hline & & & & $<0.0001$ & $<0.0001$ & 0.0031 & $<0.0001$ & 0.4218 \\
\hline \multirow[t]{2}{*}{$\mathrm{HCO}_{3}^{-}$} & & & & 1.00000 & -0.78388 & -0.57529 & 0.93571 & 0.55814 \\
\hline & & & & & $<0.0001$ & $<0.0001$ & $<0.0001$ & $<0.0001$ \\
\hline \multirow[t]{2}{*}{ Cl- } & & & & & 1.00000 & 0.87122 & -0.71601 & -0.34219 \\
\hline & & & & & & $<0.0001$ & $<0.0001$ & 0.0265 \\
\hline \multirow[t]{2}{*}{$\mathrm{Na}^{+}$} & & & & & & 1.00000 & -0.43771 & -0.15125 \\
\hline & & & & & & & 0.0037 & 0.3390 \\
\hline \multirow[t]{2}{*}{ BE } & & & & & & & 1.00000 & 0.58291 \\
\hline & & & & & & & & $<0.0001$ \\
\hline $\mathrm{pCO}_{2}$ & & & & & & & & 1.00000 \\
\hline
\end{tabular}

$\mathrm{K}^{+}$; serum potassium, $\mathrm{BC} \mathrm{K}^{+}$; buffy coat potassium, $\mathrm{Na}+$; serum sodium, $\mathrm{Cl}^{-}$; serum chloride, $\mathrm{HCO}_{3}^{-}$, bicarbonate, $\mathrm{BE}$; base excess, $\mathrm{pCO}_{2}$; partial pressure of $\mathrm{CO}_{2}$ in blood.

and negative, being -0.7 and -0.6 , respectively; there were no significant correlations with $\mathrm{BC} \mathrm{K} \mathrm{K}^{+}$, or with $\mathrm{pCO}_{2}$, values being less than 0.5 . The $\mathrm{AG}$ did not show a significant correlation with $\mathrm{BC} \mathrm{K}{ }^{+}$, serum $\mathrm{Na}^{+}, \mathrm{K}^{+}$or $\mathrm{Cl}^{-}$, nor with $\mathrm{pH}, \mathrm{HCO}_{3}{ }^{-}, \mathrm{BE}$ or $\mathrm{pCO}_{2}$ (Table 3 ).

\section{Discussion}

The values for acid-base status, $\mathrm{Na}^{+}, \mathrm{K}^{+}, \mathrm{Cl}^{-}$, haematology, biochemical profile and urinalysis in dogs from Group 1 were similar to reference values described by Willard et al. (1994) and Núñez (2001). In dogs of Group 2, with furosemide-induced hypokalemia, $\mathrm{K}^{+}$losses were increased given that this diuretic acts upon the ascending portion of the loop 
Table 3. Pearson's coefficient correlation of serum electrolytes, buffy coat potassium and blood acid-base values with strong ion difference, anion gap and ratio $\mathrm{Na}^{+}: \mathrm{K}^{+}$in blood of healthy animals (Group 1, control, $\mathrm{n}=21$ ) and in dogs with hypokalemia caused by furosemide administration ( Group 2, experimental, $\mathrm{n}=21$ )

\begin{tabular}{|ccccccccc|}
\hline Analyte & $\mathbf{K}^{+}$ & $\mathbf{B C ~ \mathbf { K } ^ { + }}$ & $\mathbf{p H}$ & $\mathbf{\mathbf { H C O } _ { 3 }}$ & $\mathbf{\mathbf { C l } ^ { - }}$ & $\mathbf{N a}^{+}$ & $\mathbf{B E}$ & $\mathbf{p C O}$ \\
$\mathbf{S I D}$ & -0.71470 & -0.34084 & 0.63934 & 0.76108 & -0.80493 & -0.40999 & 0.80127 & 0.45298 \\
& $<0.0001$ & 0.0272 & $<0.0001$ & $<0.0001$ & $<0.0001$ & 0.0070 & $<0.0001$ & 0.0026 \\
& & & & & & & & \\
$\mathbf{A G}$ & 0.16181 & 0.08960 & 0.09695 & -0.07037 & -0.21369 & 0.15658 & 0.08476 & 0.01710 \\
& 0.3060 & 0.5725 & 0.5413 & 0.6579 & 0.1742 & 0.3221 & 0.5935 & 0.9144 \\
& & & & & & & & \\
$\mathbf{N a}^{+}: \mathbf{K}^{+}$ & -0.95840 & -0.27339 & 0.47038 & 0.63050 & -0.74394 & -0.52504 & 0.59853 & 0.32450 \\
& $<0.0001$ & 0.0798 & 0.0017 & $<0.0001$ & $<0.0001$ & 0.0004 & $<0.0001$ & 0.0360 \\
& & & & & & & & \\
\hline
\end{tabular}

$\mathrm{K}^{+}$; serum potassium, $\mathrm{BC} \mathrm{K}^{+}$; buffy coat potassium, $\mathrm{Na}^{+}$; serum sodium, $\mathrm{Cl}^{-}$; serum chloride, $\mathrm{HCO}_{3}^{-}$, bicarbonate, $\mathrm{BE}$; base excess, $\mathrm{pCO}_{2}$; partial pressure of $\mathrm{CO}_{2}$ in blood, $\mathrm{SID}$; strong ion difference, $\mathrm{AG}$; anion gap, $\mathrm{Na}^{+}: \mathrm{K}^{+}$; ratio sodium-potassium

of Henle, thus blocking the $\mathrm{Na}^{+}-\mathrm{K}^{+}-2 \mathrm{Cl}^{-}$transporter (Gamba 1992; Bonagura et al. 2000). Previous experiments have described decreased serum concentrations of $\mathrm{Na}^{+}$and $\mathrm{K}^{+}$ when administering 4 to $8 \mathrm{mg} / \mathrm{kg}$ of furosemide BID for 35 days (Pereira et al. 1998). Animals of Group 2 showed results similar to those already described, with a significant decrease of $\mathrm{K}^{+}$concentration from day 21 onwards, which can be verified by looking at the mean and standard deviation compared to those of Group 1. Furosemide administration caused metabolic alkalosis due to a loss of water, $\mathrm{Na}^{+}, \mathrm{K}^{+}$and $\mathrm{Cl}^{-}$, as well as an increase in $\mathrm{HCO}_{3}^{-}$, results which are similar to those found by other authors (R o s e 1994; S e ni or 1995). The analysis of variance carried out between groups showed significant differences between $\mathrm{pH}, \mathrm{HCO}_{3}^{-}$and $\mathrm{BE}$, due to metabolic alkalosis induced by furosemide.

In order to consider $\mathrm{BC} \mathrm{K}^{+}$as an indicator of intracellular $\mathrm{K}^{+}$and the translocation process, the correlation coefficients of $\mathrm{BC} \mathrm{K}^{+}$with serum $\mathrm{K}^{+}$, as well as with other analytes used for acid-base status, were calculated. Upon determining the correlations between groups, serum $\mathrm{K}^{+}$had a positive correlation with $\mathrm{Cl}^{-}$and $\mathrm{Na}^{+}$, a negative correlation with $\mathrm{pH}, \mathrm{HCO}_{3}^{-}$and $\mathrm{BE}$, while $\mathrm{BC} \mathrm{K}^{+}$did not show high correlations with serum $\mathrm{K}^{+}$or with any other variables. The correlation found between serum $\mathrm{K}^{+}$and acid-base status could be explained by the changes in acid-base status that produce translocation of $\mathrm{K}^{+}$between ICF and ECF (Di Bartola and De Morais 1993, 2000; De Morais 1993). In general, metabolic acidosis is associated with the movement of $\mathrm{K}^{+}$from ICF to ECF, while alkalosis is associated with the movement of potassium ions from ECF to ICF (Ilkiw et al. 1989; Di Bartola and De Morais 1993). Experimental studies have found a decrease of serum $\mathrm{K}^{+}$during metabolic alkalosis, in dogs these were $0.18 \mathrm{mmol} / \mathrm{L}$ for each 0.1 increase in $\mathrm{pH}$, and up to 0.4 $\mathrm{mmol} / \mathrm{L}$ for each 0.1 of $\mathrm{pH}$ seen in respiratory alkalosis induced by hyperventilation (Mu ir et al. 1990).

The significant positive correlation of serum $\mathrm{K}^{+}$with $\mathrm{Na}^{+}$and $\mathrm{Cl}^{-}$in Group 2 can be explained by the action of the diuretic, furosemide, which causes the loss of two $\mathrm{Cl}^{-}$ions for each $\mathrm{Na}^{+}$and $\mathrm{K}^{+}$(Bonagura et al. 2000). The low correlation coefficient found between $\mathrm{BC} \mathrm{K} \mathrm{K}^{+}$and serum $\mathrm{K}^{+}$, as well as with acid-base status, means that $\mathrm{BC} \mathrm{K}^{+}$cannot be considered a good indicator of total intracellular potassium, despite having found a greater concentration of intracellular $\mathrm{K}^{+}$in $\mathrm{BC}$ when compared with the concentrations of $\mathrm{K}^{+}$in dog erythrocytes described in previous studies (Miseta et al. 1992; Catchpole and Engel 1996). 
In both groups 1 and $2, \mathrm{BC} \mathrm{K}^{+}$was found in greater concentration than that found (Di Bartola and De Morais 2000). The lower concentration of $\mathrm{BC} \mathrm{K}^{+}$does not reflect the translocation process from ECF to ICF during metabolic alkalosis, as is reflected by serum $\mathrm{K}^{+}$and acid-base values, when comparing both groups.

Acid-base status determines the translocation of $\mathrm{K}^{+}$. Evaluation of acid-base status with a blood gas analyzer allows one to know the origin of the problem, be it respiratory, metabolic or mixed; as well as the severity of these alterations and thus allows the proper diagnostic criteria for therapy and outcome (Di Bartola 2000). In clinical practice, blood gas analyzers are not always available, thus SID and $\mathrm{HCO}_{3}{ }^{-}$are so frequently used for diagnosing metabolic alkalosis and acidosis, when there is no gain of acids, and AG is used to diagnose metabolic acidosis with a gain in acids (Figge et al. 1998; Reilly and Anderson 1998)

Stewart (1983) presented a novel quantitative non-traditional method for the evaluation of acid-base disturbances of metabolic origin. This is based upon the existence of independent variables in body fluids, which include $\mathrm{pCO}_{2}$, strong ions $\left(\mathrm{Na}^{+}\right.$and $\left.\mathrm{Cl}^{-}\right)$and weak acids (proteins). The dependent variables are $\mathrm{HCO}_{3}{ }^{-}, \mathrm{OH}^{-}$and $\mathrm{pH}$. According to this theory, the dependent variables are determined by the independent variables and can be calculated through specific equations (Russsell et al. 1996). Only the independent variables can cause hydrogen ion movement in body fluids (Stewart 1983). Acid-base status can be understood in quantitative terms through the independent variables and their regulation by the lungs, kidneys, gastrointestinal tract and liver. In the last few years there has been a tendency to apply Stewart's concepts in evaluating acid-base status in human medicine (Fencl and Leith 1993).

It was deemed important to establish the relationship between SID, $\mathrm{AG}$ and $\mathrm{Na}^{+}: \mathrm{K}^{+}$with $\mathrm{BC}$ $\mathrm{K}^{+}$, and serum $\mathrm{K}^{+}, \mathrm{Na}^{+}$and $\mathrm{Cl}^{-}$, as well as with the values used to determine acid-base status $\left(\mathrm{pH}, \mathrm{HCO}_{3}^{-}, \mathrm{BE}\right.$ and $\left.\mathrm{pCO}_{2}\right)$ in both the control and furosemide-induced hypokalemic group.

In the results of the statistical analysis for the groups, SID presented a significant positive correlation coefficient with $\mathrm{HCO}_{3}{ }^{-}$and $\mathrm{BE}$, thus corroborating its utility in the diagnosis of metabolic alkalosis (Russell et al. 1996). A significant negative correlation coefficient with serum $\mathrm{K}^{+}$indicated that SID is a good parameter for evaluating the translocation that occurs due to metabolic translocation.

The AG in the experimental group did not show significant correlation with any of the electrolytes, or with the values of acid-base status. This can be explained due to the fact that AG is only useful for the diagnosis of metabolic acidosis when there is an overall gain in organic acids, sulphates and phosphates (Reilly and Anderson 1998).

In conclusion, under the conditions of the present study, $\mathrm{BC} \mathrm{K}^{+}$did not turn out to be a better index than serum $\mathrm{K}^{+}$in diagnosing deficit or excess of total body $\mathrm{K}^{+}$. BC $\mathrm{K}^{+}$did not have a significant correlation with acid-base status, as was found to be the case for serum $\mathrm{K}^{+}$. Acid-base status determines the process of translocation, thus explaining the significant correlation coefficients found with serum $\mathrm{K}^{+}$. SID is a good indicator of the translocation process in metabolic alkalosis but not in metabolic acidosis concurrent with acid gain. AG is only a good indicator of the translocation process if metabolic acidosis involves a gain in acids.

\section{Koncentrace draslíku v buffy coat, krevním séru a její vztah k acidobazickému stavu zdravých psů a psů s hypokalemií}

Poruchy metabolismu elektrolytů a acidobazické rovnováhy jsou u psů časté. Cílem práce bylo stanovit koncentrace $\mathrm{K}^{+} \mathrm{v}$ krevním séru a koncentrace $\mathrm{K}^{+} \mathrm{v}$ buffy coat $\left(\mathrm{BC} \mathrm{K}^{+}\right.$) a jejich vztah $\mathrm{k}$ elektrolytům $\mathrm{v}$ krevním séru a acidobazickým hodnotám zdravých a hypokalemických psů. Studie byla provedena na 42 psech obou pohlaví, stáří 3-8 roků. Psi byli 
rozděleni do dvou skupin. Skupina 1 (kontrolní, $\mathrm{n}=21$ ) byla tvořena zdravými psy, skupina 2 (pokusná, $\mathrm{n}=21$ ) sestávala ze zdravých psů, u kterých byla vyvolána hypokalemie, a to perorální aplikací furosemidu v dávce $12 \mathrm{mg} / \mathrm{kg}$ ž. hm. po dobu 21 dnů. Klinické vyšetření, hematologický profil (16 analytů), biochemický profil (22 analytů) a analýzy moči (15 analytů) byly hodnoceny u všech psů. Nejdůležitějšími analyty v krevním séru byly $\mathrm{Na}^{+}, \mathrm{K}^{+}$ a $\mathrm{Cl}^{-} ; \mathrm{BC} \mathrm{K}^{+}$a v krvi pH, $\mathrm{HCO}_{3}^{-}$, base excess $(\mathrm{BE})$ a $\mathrm{pCO}_{2}$. Byla vypracována metoda pro stanovení intracelulárního $\mathrm{K}^{+} \mathrm{v}$ BC. Mezi skupinami 1 a 2 koncentrace $\mathrm{K}^{+} \mathrm{v}$ krevním séru korelovala signifikantně s $\mathrm{pH}, \mathrm{HCO}_{3}^{-} \mathrm{a} \mathrm{BE}(\mathrm{r}>0.6, p<0.01)$; navíc ve skupině 2 byla zjištěna $\mathrm{v}$ důsledku účinku furosemidu signifikantní korelace s koncentracemi $\mathrm{Na}^{+} \mathrm{a} \mathrm{Cl}-(\mathrm{r}>0.7, p<$ 0.01). Koncentrace $\mathrm{K}^{+} \mathrm{v}$ BC vykázala nízkou korelaci s $\mathrm{K}^{+} \mathrm{v}$ krevním séru a ostatními sledovanými krevními analyty a tudíž nemůže být považována za vhodný ukazatel funkce intracelulárního $\mathrm{K}^{+}$. Korelační koeficienty ve skupinách 1 a 2 byly signifikantní mezi diferencí silných iontů (SID), $\mathrm{K}^{+}, \mathrm{Cl}^{-}, \mathrm{HCO}_{3}^{-}$a $\mathrm{BE}(\mathrm{r}>0.7, p<0.01)$, z čehož vyplývá, že SID je vhodným ukazatelem translokace $\mathrm{K}^{+}$pri metabolické alkalóze. Anion gap (AG) nekoreloval s $\mathrm{BC} \mathrm{K}^{+}$, se $\mathrm{Na}^{+}, \mathrm{K}^{+} \mathrm{a} \mathrm{Cl}^{-}$v krevním séru a rovněž s $\mathrm{pH}, \mathrm{HCO}_{3}^{-}, \mathrm{BE}$ a pCO 2 v krvi. Pro vyhodnocení acidobazických poruch je nutné zařadit do laboratorních profilů stanovení $\mathrm{K}^{+}, \mathrm{Na}^{+}, \mathrm{Cl}^{-}, \mathrm{HCO}_{3}^{-} \mathrm{v}$ krevním séru, stejně jako výpočet $\mathrm{AG}$ a SID a interpretovat je v návaznosti na klinické vyšetření zvířat.

\section{References}

BELLENGER CR, MADDISON JE, MACPHERSON GC, ILKIW JE 1990: Chronic hypertrophic pyloric gastropathy in 14 dogs. Aust Vet J 67: 317-320

BILBREY GL, HERBIN L, CARTER NW 1973: Skeletal muscle resting membrane potencial in potassium deficiency. J Clin Invest 52: 3011-3014

BONAGURA JD, LEHMKUHL DE, DE MORAIS HA 2000: Fluid and diuretic therapy in heart failure. In Di Bartola SP: Fluid therapy in small animal practice. $2^{\text {nd }}$ ed., WB Saunders, Philadelphia, pp. 387-409

BROBST D 1989: Urinalysis and associated laboratory procedures. Vet Clin N Am-Small Anim Pract 19: 929-941

CATCHPOLE HR, ENGEL MB 1996:Microprobe analysis of element distribution in rabbit and dog erythrocytes as examples of "high" and "low" potassium cells. Scan Micro 10: 745-751

DI BARTOLA SP 2000: Introduction to acid-base disorders. In Di Bartola SP: Fluid therapy in small animal practice. $2^{\text {nd }}$ ed., WB Saunders, Philadelphia, pp. 189-210

DI BARTOLA SP, DE MORAIS HA. 1993: Mixed acid-base disorders. Clinical approach. Comp Cont Educ Pract Vet 15: 1619-1622

DI BARTOLA SP, DE MORAIS HA 2000: Disorders of potassium: hypokalemia and hyperkalemia. In Di Bartola SP: Fluid therapy in small animal practice. $2^{\text {nd }}$ ed., WB Saunders, Philadelphia, pp. 83-107

DI BARTOLA SP, GREEN RP, DE MORAIS HA 1994: Electrolyte and acid-base. In Willard MD, Tvedten H, Turnwald GH 1994: Small animal clinical diagnosis by laboratory methods. $2^{\text {nd }}$ ed., WB Saunders, Philadelphia, pp. $97-146$

FENCL V, LEITH DE. 1993: Stewart's quantitative acid-base chemistry: Applications in biology and medicine. Resp Physiol 91: 1-5

FIELD MJ, BERLINER RW, GEIBISCH GH 1987: Regulation of renal potassium metabolism. In: Maxwell MH, Kleeman GR, Narins RG: Clinical disorders of fluid and electrolyte metabolism. McGraw-Hill Book, New York, pp. 119-146

FIGGE J, KAZDA A, FENCL V 1998: Anion gap and hypoalbuminemia. Crit CareMed 26: 1807-1817

GAMBA G 1992: Biología molecular de la reabsorción renal de sodio. Invest Clin 44: 545-562

HENDRIX PK, RAFFE MR 1994: Fluid, electrolyte, and acid-base disorders, disease mechanisms in small animal surgery. In Bojrab MJ: Disease mechanisms in small animal surgery. $2^{\text {nd }}$ ed., Lea \& Fibiger, Philadelphia, pp. 21-31

ILKIW JE, DAVIS PE, CHURCH DB 1989: Haematologic, biochemical, blood gas, and acid-base values in greyhounds before and after exercise. Am J Vet Res 50: 583-590

KIRK WR 1980: Disorders of potassium: hypokalemia and hyperkalemia. $4^{\text {th }}$ ed., WB Saunders, Philadelphia, $1358 \mathrm{p}$.

KNOLL JS 2000: Clinical automated haematology systems. In Feldman BF, Zinkl JG and Jain NC: Schalm's Veterinary Haematology. $5^{\text {th }}$ ed., Lippincott, Philadelphia, pp. 3-11

KORNEGAY JN 1995: Disorders of the skeletal muscles. $4^{\text {th }}$ ed., WB Saunders, Philadelphia, pp. 727-736

LEES GE, WILLARD MD, GREEN RA 1994: Urinary disorders. In Willard MD, Tvedten H, Turnwald GH: Small animal clinical diagnosis by laboratory methods. WB Saunders, Philadelphia, pp. 115-146

MACINTIRE DK 1997: Disorders of potassium, phosphorus, and magnesium in critical illness. Comp Cont Educ Pract Vet 19: 41-49 
MEYER DJ, COLES EH, RICH LJ 1992: Veterinary laboratory medicine. Interpretation and diagnosis. WB Saunders, Philadelphia, pp. 71-81

MISETA A, SOMOSKEOYS, GALAMBOS C, KELLERMAYER M, WHEATLEY DN, CAMERON IL 1992: Human and dog erythrocytes: relationship between ATP levels, ATP consumption and potassium concentrations. Physiol Chem Phys Med 24: 11-20

MUIR WW, WAGNER AE, BUCHANAN C 1990: Effects of acute hyperventilation on serum potassium in the dog. Vet Surg 19: $83-87$

NÚNEZ OL 2001: Pruebas de laboratorio. In Diplomado a distancia en medicina cirugía y zootecnia en perros y gatos. $2^{\text {nd }}$ ed., Universidad Nacional Autónoma de México, México D.F., pp. 167-198

PEREIRA JDG, CAMACHO AA, SANTANA AE, CARVALHO MB 1998: Sodium and potassium values in serum and urine and electrocardiography parameters in dogs treated with furosemide. Arq Bras Med Vet Zoot 50: 677-684

PHILLIPS SL, POLZIN DJ 1998: Clinical disorders of potassium homeostasis: Hyperkalemia and hypokalemia. Vet Clin N Am-Small Anim Pract 28: 545-564

REILLY RF, ANDERSON RJ 1998: Interpreting the anion gap. Crit Care Med 26: 1771-1773

ROSE BD 1994: Clinical physiology of acid-base and electrolyte disorders. $2^{\text {nd }}$ ed., McGraw-Hill, New York, $811 \mathrm{p}$.

RUSSELL KE, HANSEN BD, STEVENS JB 1996: Strong ion difference approach to acid-base imbalances with clinical applications to dogs and cats. Vet Clin N Am-Small Anim Pract 26: 981-987

SAS:SAS/STAT user's guide. 1990: Volume 2 GLM-VARCOMP. Version 6, 4th ed., Cary(NC): SAS Institute Inc. SCHAER M 1993: Sodium and potassium disorders. Vet Cont Educ 152: 147-154

SCHAER M 1993a: Complications encountered in treating the diabetic dogs. Vet Cont Educ 152: 23-27

SENIOR DF 1995: Fluid therapy, electrolytes, and acid-base control. In Ettinger SJ, Feldman EC: Veterinary internal medicine. $2^{\text {nd }}$ ed., WB Saunders, Philadelphia, pp. 294-312

STEWART PA 1983: Modern quantitative acid-base chemistry. Can J Pharmacol 61: 1444-1461

WILLARD MD, TVEDTEN H, TURNWALD GH 1994: Small animal clinical diagnosis by laboratory methods. WB Saunders, Philadelphia, 365 p. 